\title{
The Effectiveness of Cutaneous Stimulation and Cuddling Therapy Combination on Toddler's Pain Response
}

\author{
$1^{\text {st }}$ Eva Oktaviani \\ Lubuklinggau Nursing Study Program \\ Poltekkes Kemenkes Palembang \\ Lubuklinggau, Indonesia \\ Email: nersevaoktaviani@gmail.com
}

\author{
$2^{\text {nd }}$ Indah Dewi Ridawati \\ Lubuklinggau Nursing Study Program \\ Poltekkes Kemenkes Palembang \\ Lubuklinggau, Indonesia \\ Email: indahdewiridawati@gmail.com
}

Corresponding author: nersevaoktaviani@gmail.com

\begin{abstract}
The high number of morbidity has an effect on the high number of children hospitalization cases, resulting in children vulnerable to stress. Installation of infusion is one of the most invasive measures during child nursing and can cause pain. The purpose of this study is to determine the effectiveness of cutaneous stimulation and cuddling therapy combination during infusion on toddler's pain response in the nursery of Siti Aisyah Regional Hospital in 2019. The design of the study is an action research with posttest_only control group design. Behavioral and physiological pain responses in the form of pulse frequencies in the two groups will be observed and compared. Forty-eight children in the study sample were divided into two groups; the intervention group $(n=24)$ with a combination of cutaneous stimulation and cuddling therapy and the control group $(n=24)$ with only cutaneous stimulation were taken by consecutive sampling. Analysis is done using Mann Whitney. There are significant differences in pain scale and average pulse between the two groups. The combination of cutaneous stimulation in the form of cold pack and cuddling therapy has proven to be effective as a nonpharmacological therapy that can be applied in children's room as part of a child nursing.
\end{abstract}

Keywords: cold compress, cutaneous stimulation, cuddling therapy, toddler

\section{INTRODUCTION}

Pain and hospitalization is a major form of stressor and is the first crisis for children. Children are very susceptible to stress as a result of changes in healthy conditions and routine in the hospital environment. This situation occurs because of the limitations of children in providing defense mechanisms to deal with stressors [1]. Hospitalization is a process for planning or emergency that requires children to be hospitalized and undergo therapy and treatment. Hospitalization will cause children to experience short-term or long-term trauma [2]. Children will experience a variety of feelings during hospitalization such as anger, sadness, fear, feeling guilty, and anxiety [1].

The National Hospital Discharge Survey (2015) estimates that more than $1.6 \%$ of children undergo hospitalization in the age of 2-6 years for various reasons. The same thing also explained that the prevalence of children's anxiety during hospitalization reached $75 \%$. Children aged 0-17 years experienced $18.1 \%$ pain and around $2.78 \%$ had been hospitalized in the past year with the highest child morbidity rate at the age of $0-4$ years. The high rate of morbidity is causing the increase of hospitalization cases of children.

Invasive measures such as injection, infusion, blood sampling constitute the majority of the procedural majority experienced by children during hospitalization and most of these procedures result in distress [3]. Infusion is the second source of pain most felt by children after the disease [4]. Pain is the main source of distress for children, families and also health care providers [5].

Empirical evidence shows that unrelieved pain in children has only harmful consequences, with no 
benefits. If pain in children is not managed properly, it can cause serious physical and emotional consequences, such as increased oxygen and changes in metabolism of oxygen consumption, and changes in blood glucose metabolism [5]. Effective pain management needs to be managed proactively through a therapeutic approach that involves a combination of pharmacology and nonpharmacology [6]. One physical technique that can be used to reduce pain sensation is cutaneous stimulation, which is a technique to provide physical stimulation to the skin that can reduce pain by giving cold compress. This skin stimulation technique is also an effort to apply the concept of atraumatic care to children when an invasive procedure is given. Previous studies of cold compresses have been shown to reduce pain in children [7], [8].

This is also reinforced by research conducted by de Breving, Ismanto, and Onibala (2015) who applied the concept of atraumatic care in the form of giving cold compress during infusion significantly reduce children's anxiety during hospitalization [9].

Distress is very important to be minimized both for parents and children during hospitalization and especially during invasive procedures to reduce the risk of impacts after invasive procedures and facilitate the development of child coping. Minimizing the impact of distress on children also helps reduce stress on parents and health workers. The relationship between parental anxiety and child stress during invasive procedures is very strong [10]. The presence of parents has an advantage during the invasive procedure. Previous studies have explained that children prefer their parents to be present during care and that parental presence can reduce distress [11]. Parents' presence is more effective than health care professionals in offering assistance. Parents can play a role in providing support through position, cuddling, touching, distraction as a form of coping strategies during the hospitalization phase of the child [10]. Cuddle therapy is one of the ways to make children comfortable and help them maintain their position during the treatment procedure. Therefore, it will help health workers in taking action or giving the treatment. It will also avoid forced treatment on the children [12].

One of nursing strategies to include families in child care is the application of cuddle therapy during infusion. Spark, Setlik, and Luhman (2007) in their research point out that the positive effect of the parent's hug can reduce the distress of the child during the infusion [13]. Cuddling techniques make children feel comfortable and help them maintain a comfortable position during the procedure. Cuddle therapy is also in line with other principles of child nursing that is empowering families in the interventions provided (family centered care) [2]. The presence of parents during the procedure is a partnership between family and professional nurses. Baucher et al., (2006) affirm that family presence does not negatively impact the medical performance of being with their child and it shows reduced parental anxiety [14]. In addition, Lestari (2013) believes that there are differences in the average distress score in children who are given the parent's cuddle (2.30) and the distress score of children who do not get a parent's cuddle (3.25) [15].

During infusion, restraints and uncomfortable positions may increase psychological stress faced by both children and families. Psychological distress gives adverse influence to the healing process of the patient. The release of stress hormones occurs under stress conditions, including cortisol which can cause pressure on the child's immune system, so that the children are susceptible to secondary infections which extend hospital treatment days [16]. Physiological responses such as elevated heart rate, respiratory frequency and decreased oxygen saturation may indicate stress conditions in children.

Another problem phenomenon found in the field based on observations and interviews in the nursery is that during the installation of infusion, atraumatic care has not been carried out effectively. Parents have not been fully involved in children nursing during invasive measures, and the position of supination and restrain during the installation of infusion is still an option, thus making children even more frightened. Combining embrace therapy and cold compresses can provide a double benefit, in addition to providing a rapid analgesic effect, health workers will be helped by the child's correct position when the infusion is administered. Based on this, the researchers felt the importance of the study by combining the two interventions to see the effectiveness of the combination of cutaneous stimulation interventions and cuddling therapy during infusion in toddler on pain responses in Lubuklinggau Regional Hospital in 2019.

\section{METHOD}

This research is a quantitative study using action research with posttest only control group design. Pain response is measured by the FLACC instrument for behavioral response and pulse oximetry to measure the highest average pulse frequency during the installation of infusion. Subjects were divided into two groups, namely the intervention group with a combination of cutaneous stimulation and cuddling therapy and the 
control group with only cutaneous stimulation, then posttest were applied to both groups. Cutaneous stimulation is given with a cold compress for 3 minutes prior to infusion. The total sample was 48 children with each group of 24 children taken by consecutive sampling. Ethics test was obtained from UNISA Yogyakarta Ethics Commission.

\section{R E S U L T S}

Table 1 Characteristics of respondents in the intervention group and control group at Siti Aisyah regional hospital, August-October $2019(n=48)$

\begin{tabular}{llcccc}
\hline \multirow{2}{*}{ Characteristics } & \multicolumn{2}{c}{$\begin{array}{c}\text { Total of } \\
\text { Sample }\end{array}$} & \multicolumn{2}{c}{ Group } & \\
\cline { 3 - 5 } & & $\mathrm{n}(\%)$ & $\begin{array}{c}\text { Control } \\
\mathrm{n}(\%)\end{array}$ & $\begin{array}{c}\text { Intervention } \\
\mathrm{n}(\%)\end{array}$ & $p, \mathrm{x}^{2}$ \\
\hline Gender & Male & $25(52,1)$ & $12(50)$ & $13(54,2)$ & 1,000 \\
& Female & $23(47,9)$ & $12(50)$ & $11(45,8)$ & \\
Age & 1-2,5 years & $39(43,7)$ & $17(33,3)$ & $22(54,2)$ & 0,137 \\
& $2,6-3$ years & $9(37,5)$ & $7(37,5)$ & $2(37,5)$ & \\
Hospitaliz & No & $47(97,9)$ & $23(95,8)$ & $24(100)$ & 1,000 \\
ation & Yes & $1(2,08)$ & $1(4,2)$ & - & \\
$\begin{array}{l}\text { Experienc } \\
\text { e }\end{array}$ & & & & & \\
\hline
\end{tabular}

The results of univariate analysis in the group category are obtained from the table 1 that the total number of respondents was 48 children with details of each of 24 children for the intervention group and 24 children for the control group. The difference in the number of male and female respondents in the two groups is not too large, in total $52.1 \%$ for male and $47.9 \%$ for female.

The majority of toddler in both groups were at age 12.5 years which was $43.7 \%$. Based on table 4.1 , it can be seen that the majority of respondents have never had hospitalization or previous treatment experience, namely $97.9 \%$.

Table 2. Frequency Distribution Of Pain Scale And Pulse frequency variable in the intervention group and control group at Siti Aisyah regional hospital, August-October $2019(n=48)$

\begin{tabular}{|c|c|c|c|c|c|}
\hline \multirow{3}{*}{ Variable } & \multicolumn{5}{|c|}{ Group } \\
\hline & \multicolumn{3}{|c|}{ Cutanoeus Stimulation } & \multicolumn{2}{|c|}{$\begin{array}{c}\text { Cutanoeus Stimulation } \& \\
\text { Cuddling Therapy }\end{array}$} \\
\hline & Mean & $\begin{array}{l}\text { SD } \\
\text { Range }\end{array}$ & Range & Mean & SD \\
\hline Pain Scale & 4,46 & $\begin{array}{c}1,693 \\
1-5\end{array}$ & $2-8$ & 2,29 & 1,233 \\
\hline Pulse & 138,50 & $\begin{array}{l}9,455 \\
98-136\end{array}$ & $6^{120-158}$ & 115,29 & 13,392 \\
\hline
\end{tabular}

Table 2 analysis results show that the average pain scale in the control group is greater than the intervention group, which is 4.46 compared to 2.29 . The average change in pulse frequency during infusion in the control group was higher than the intervention group at 138,50 compared to 115,29 .

Table 3.Difference in pain scale and pulse between intervention group and control groups at Siti Aisyah regional hospital, August-October $2019(\mathrm{n}=48)$

\begin{tabular}{|c|c|c|c|c|c|}
\hline $\begin{array}{c}\text { Variab } \\
\text { le }\end{array}$ & Group & $\mathrm{N}$ & $\begin{array}{l}\text { Mean } \\
\text { Rank }\end{array}$ & $\begin{array}{c}\text { Median } \\
\text { (Min-Mak) }\end{array}$ & $P$ Value \\
\hline \multirow{3}{*}{$\begin{array}{l}\text { Pain } \\
\text { Scale }\end{array}$} & Control & 24 & 33,02 & $4(2-8)$ & $0,001^{*}$ \\
\hline & Intervention & 24 & 15,98 & $2(1-5)$ & \\
\hline & Control & 24 & 34,81 & $138(120-158)$ & $0,001^{*}$ \\
\hline Pulse & Intervention & 24 & 14,19 & $116,5(98-136)$ & \\
\hline
\end{tabular}

The results of the analysis in table 3 show that there is a significant difference in the pain scale and average pulse during infusion performed only by cutaneous stimulation compared to the one with a combination of cutaneous stimulation and cuddling therapy.

\section{DISCUSSION}

The results of this study showed that from the total sample as a whole, it was found that the number of male and female was not too different. Mathew (2003) explained that the gender differences do not really matter in pain, the gender differences only because sensitivity of experience and situasional condition that influence how children respon for pain [17]. Schmitz, Vierhaus, and Lohaus (2012) also explained that in general male and female are not significantly different in responding to pain [18].

Other researchs prove that gender differences greatly influence pain [19], [20], [21]. This research links endogenous opioid neurotransmitters, found that male endogenous opioids are higher than women [19]. From the characteristics of respondents, results obtained from the age of respondents from the total sample of toddlers age 1-2.5 years as much as $43.7 \%$. Child's age development influences the meaning of pain and the expression that is raised [22]. Toddler age has not been able to control the pain response. Pain response at this age will be indicated by verbal indicators and changes in behavioral activity. At toddler age the pain response that is raised is more expressive because it is still unable to describe the specific pain felt due to limited vocabulary. 
The majority of the total sample is respondents who have never been hospitalized is $97.9 \%$. Smeltzer and Bare (2001) say that previous experience influences one's pain perception about pain [23]. Previous experiences will cause fear when facing the next painful event. Noel et al. (2012) conducted a study of the effect of children's experiences on new pain stimuli on subsequent pain experiences [24].

The results of the analysis using Mann Whitney showed that there was a significant difference in the pain scale during infusion performed by only cutaneous stimulation compare to the combination of cutaneous stimulation and cuddling therapy ( $\mathrm{p}$ value $<\alpha$ ). Cutaneous stimulation in the form of cold compresses has proven to be effective in reducing pain scale during infusion combined with cuddling therapy.

Medical procedures are an unpleasant experience for children, parents and professionals in the health sector. Hence, an approach is needed to enhance the comfort of children, parents and medical staff. Stephens (1999) provides a model approach in 5 parts, namely: 1) Preparing children and parents for the procedure and their role during the procedure, 2) Presenting parents during the treatment, 3) Preparing a comfortable room/environment during the treatment, 4) Positioning the child comfortably during the treatment, 5) Maintaining a positive atmosphere after the treatment [25]. The involvement of parents is an significant factor in applying this model when the care procedure is performed as it has been demonstrated that it can alleviate child distress and be helpful to health workers during care. Another approach that also prioritizes the presence of parents in child care is explained by Lerwick (2016), namely CARE model which includes: 1) Choice: giving strength in the care environment, 2) Agenda: asking patient and family expectations, 3) Resilience: starting with strength owned by patients and families, 4) Emotion: recognizing the fear response of children and families. The CARE process is believed to be able to minimize distress during child care procedures [26].

Sparks, Setlik, and Luhman (2007) in their study explained that parents' embrace can reduce child distress during infusion [13]. The presence of parents during the procedure is a partnership between family and professional nurses which is an application from family center care (FCC). Cuddling therapy is the use of a comfortable, safe, and temporary position that provides close physical contact with a trusted parent or family [2]. This method helps children by allowing them to manage or deal with painful procedures easily and effectively and give children a sense of control. Cuddling therapy can help minimize pain scale, it can also be explained that family cuddling can provide comfort to the children and sufficient immobilization when the child is to be infused. Children who are calm before the infusion will require less time and fewer nurses compared to children who are angry and refuse to receive treatment.

During the hospitalization phase children will face interventions that might cause trauma, stress, and pain. Health professionals in hospitals have the responsibility to reduce pain and anxiety as much as possible by prioritizing patient safety [27]. Optimizing pain management is the privilege of all patients and the duty not just of nurses but also of all health professionals because it is multidisciplinary science. Therefore, Efforts are required to alleviate emotional issues and avoid the physical effects of pain-causing treatments and the long-term effects of pain in children. Pediatric patients need the health staff to provide additional care. Every health professional has a valuable opportunity inside a medical setting to monitor the negative outcome of pediatric stress. Therefore, understanding the risk of anxiety and trauma in pediatric patients needs to be addressed by all health professions that offer inpediatric hospitalization services.

Cutaneous stimulation is physical stimulation of the skin that can reduce pain such as cold compresses that can reduce blood flow to some body part and reduce edema which is expected to provide analgesic effect by slowing the speed of nerve delivery, so that the pain that reaches the brain is less [28]. The combination of the two can cause a greater and faster analgesic effect in children, resulting in the average pain scale in the intervention group being smaller than in the control group.

Pain will result in changes in the increase or decrease in physiological function parameters of the body namely heart rate, breathing frequency, blood pressure, and oxygenation to tissues [29]. The mechanism of physiological changes is a defense response from the body because pain activates the right hemisphere brain region to release the body's defense response through the release of hormones (corticosteroids, vasopressin, and oxytocin), increased heart rate, and energy mechanisms [30]. Table 3 shows that there is a significant difference in the average pulse frequency in the group with a combination of cutaneous stimulation and cuddling therapy compared to the one with only cutaneous stimulation during infusion. The increase in pulse rate 
during the infusion occurred in both groups, but the average increase in pulse frequency was greater in the control group. This is because the intervention group carried out a combination of nonpharmacological interventions, namely cold compresses that can cause analgesic effects coupled with cuddling therapy in children. This cuddling therapy makes the children in the intervention group more comfortable, so the stress level will decrease and the recovery phase will be faster.

Research conducted by Sembiring, Novayelinda, and Nauli (2015) compared the differences in pulse frequency in toddlers and pre-school children when infusion was installed, the results obtained toddler have a faster pulse frequency $(95.77 \mathrm{x} /$ minute) compared to pre-school (89.92/minute) [31]. The increase in the average pulse rate at toddler age is also caused because at this age the child does not yet have a higher readiness when infusion is performed and has not been able to tolerate the pain they feel. Kirkpatrick and Tobias (2013) revealed that the physiological reaction of toddler age pulse and breathing experienced an increase in pain [32].

Cuddling therapy can reduce child pain and distress during the procedure and this means parents play a role in calming and stimulating distraction in children [33]. In principle, the distraction technique is a way to divert the child's focus from pain to other activities that are fun for the child [34]. Distraction techniques can inhibit the work of the sympathetic nervous system, so the production of neurotransmitters is inhibited so that the pulse, blood pressure and other physiological responses which are signs of anxiety can return to normal [35]. Distraction and comfort can be provided parents by parents with physical touch (eg. Cradling and cuddling) [36]. Parental activity during diagnosis or medical procedures is the best factor of children's handling of anxiety and coping. It is supported by a research conducted by Mougianis, Cohen, and Shih (2017) on parent interaction activities in children during immunization. The study explains that the parents ' comfort may be in the form of physical (cuddle, touch) or verbal aspects [37].

\section{CONCLUSION}

This study proves that the combination of cutaneous stimulation and cuddling therapy has been shown to be effective in reducing pain in children. This can be seen from the difference in the average pain scale in the intervention group and control group and the higher pulse rate in the control group.

\section{ACKNOWLEDGMENT}

The authors acknowledge with grateful appreciation the participating families. This study was supported by institute of research and community service Poltekkes Kemenkes Palembang and Lubuklinggau Nursing Study Program. We gratefully acknowledge Director of Siti Aisyah regional hospital, Head Nurse, all doctors and nurses pediatric and emergency ward.

\section{REFERENCES}

[1] D. L. Wong et al. Nursing care of Infants and Chidren. Missouri: Mosby Company Incorporated; 2009.

[2] D. L. Wong et al. Wong's Nursing Care Of Infants and Children (8th ed). 8th ed. Louis: Mosby Company Incorporated; 2012

[3] Fadeelah Mansour Ahmed Alalo, Awatef El Sayed Ahmad, Hoda Mohamed Nafee El Sayed. Pain Intensity After an Ice Pack Application Prior to Venipuncture among Schoolage Children: An experimental Study. J Educ Pract 2016;7:16-25.

[4] Kennedy RM, Luhmann J, Zempsky WT. Clinical Implications of Unmanaged Needle-Insertion Pain and Distress in Children. Pediatrics 2008;122. https://doi.org/10.1542/peds.2008-1055e.

[5] T. Kyle and SC. Buku Ajar Keperawatan Pediatrik. Jakarta: EGC; 2012.

[6] American Academy of Pediatrics. American Academy of Pediatrics. 2013

[7] Indriyani P, Hayati H, Chodidjah S. Kompres Dingin dapat Menurunkan Nyeri Anak Usia Sekolah Saat Pemasangan Infus. J Keperawatan Indones 2013;16:93-100. https://doi.org/10.7454/jki.v16i2.7.

[8] Canbulat N, Ayhan F, Inal S. Effectiveness of External Cold and Vibration for Procedural Pain Relief During Peripheral Intravenous Cannulation in Pediatric Patients. Pain Manag Nurs 2015;16:33-9. https://doi.org/10.1016/j.pmn.2014.03.003.

[9] de Breving RM, Ismanto A, Onibala F. Pengaruh Penerapan Atraumatic Care Terhadap Respon Kecemasan Anak yang Mengalami Hospitalisasi Di Rsu Pancaran Kasih Gmim Manado Dan Rsup Prof. Dr. R. D. Kandou Manado. J Keperawatan UNSRAT 2015;3:108829.

[10] The British Psychological Society. Evidence-based Guidelines for The Management of Invasive and/or Distressing Procedures with Children. Br Psychol Soc 2010:1-48

[11] Waseem M RM. Parental Presence During Invasive Procedures in Children: What Is The Physician's Perspective? Ann Emerg Med 2004;44:432-3. https://doi.org/10.1016/j.annemergmed.2004.07.439.

[12] Cavender K, Goff MD, Hollon EC, Guzzetta CE. Parents' Positioning and Distracting Children During Venipuncture: Effects on Children's Pain, Fear, and Distress. J Holist Nurs

https://doi.org/10.1177/0898010104263306

[13] Sparks LA, Setlik J, Luhman J. Parental Holding and Positioning to Decrease IV Distress in Young Children: A Randomized Controlled Trial. J Pediatr Nurs 2007;22:4407. https://doi.org/10.1016/j.pedn.2007.04.010.

[14] MD Howard Bauchner, Robert Vinci, MPH Sharon Bak, Colleen Pearson MMJC. Parents and Procedures: A Randomized Controlled Trial. Pediatrics 1996;98:861-7.

[15] Lestari KB. Dampak Dekapan Keluarga dan Posisi Duduk Terhadap Distress Anak Saat Dilakukan Pemasangan Infus. Universitas Indonesia, 2013. 
[16] A.C. Guyton and JEH. Buku Ajar Fisiologi Kedokteran. 9th ed. Jakarta: EGC; 2007.

[17] Mathew PJ, Mathew JL. Assessment and management of pain in infants. Postgrad Med J 2003;79:438-43. https://doi.org/10.1136/pmj.79.934.438.

[18] Schmitz AK, Vierhaus M, Lohaus A. Pain tolerance in children and Adolescents: Sex differences and psychosocial influences on pain threshold and endurance. Eur J Pain (United Kingdom) 2013;17:124-31. https://doi.org/10.1002/j.1532-2149.2012.00169.x.

[19] Zubieta JK, Smith YR, Bueller JA, Xu Y, Kilbourn MR, Jewett DM, et al. $\mu$-opioid Receptor-Mediated Antinociceptive Responses Differ in Men and Women. J Neurosci $2002 ; 22: 5100-7$ https://doi.org/10.1523/jneurosci.22-12-05100.2002.

[20] Asriani NK, Lestiawati E, Retnaningsih LN. Pengaruh Kompres Dingin Terhadap Tingkat Nyeri Anak Usia Sekolah Saat Pemasangan Infus di Poliklinik Persiapan Rawat Inap Rsud Panembahan Senopati Bantul. J Keperawatan Respati Yogyakarta 2017;4:70-5.

[21] Kunjumon D. Effect of Kaleidoscope on Pain Perception of Children Aged 4-6 Years During Intravenous Cannulation. $\begin{array}{lllll}\text { Am J Nurs } & \text { Sci }\end{array}$ https://doi.org/10.11648/j.ajns.20180704.14.

[22] L. C. M. Craig Kenneth GCA. Barriers to optimal pain management in infants, children, and adolescents social barriers to optimal pain management in infants and children. Clin J Pain 1996;2:232-42.

[23] S.C. Smeltzer and BGB. Buku Ajar Keperawatan Medikal Bedah Brunner \& Suddarth. 8th ed. Jakarta: EGC; 2002.

[24] Noel M, Chambers CT, McGrath PJ, Klein RM, Stewart SH. The Influence of Children's Pain Memories on Subsequent Pain Experience. Pain 2012;153:1563-72. https://doi.org/10.1016/j.pain.2012.02.020.

[25] Stephens BK. Techniques to Comfort Children During Stressful Procedures. Adv Mind Body Med 1999;15:49-60.

[26] Lerwick JL. Minimizing Pediatric Healthcare-Induced Anxiety and Trauma. World J Clin Pediatr 2016;5:143. https://doi.org/10.5409/wjcp.v5.i2.143.

[27] Srouji R, Ratnapalan S, Schneeweiss S. Pain in Children: Assessment and Nonpharmacological Management. Int $\mathrm{J}$ Pediatr https://doi.org/10.1155/2010/474838.

[28] S. A. Price and LMW. Patofisiologi: Konsep Klinis Proses-proses Penyakit. Jakarta: EGC; 2006.

[29] Eckstein Grunau R. Neonatal Pain in Very Preterm Infants: Long-Term Effects on Brain, Neurodevelopment and Pain Reactivity. Rambam Maimonides Med J 2013;4:1-13. https://doi.org/10.5041/rmmj.10132.

[30] Ozawa M, Kanda K, Hirata M, Kusakawa I, Suzuki C. Influence of repeated painful procedures on prefrontal cortical pain responses in newborns. Acta Paediatr Int J Paediatr 2011;100:198-203. https://doi.org/10.1111/j.16512227.2010.02022.x.

[31] Sada Ulina Sembiring, Riri Novayelinda Fathra AN. Perbandingan Respon Nyeri Anak Usia Toddler dan Prasekolah yang Dilakukan Prosedur Invasif 2015;2:1491500.

[32] Kirkpatrick KTT. Pediatric Age Specific: Self Learning Module. 2013.

[33] Berberich FR, Landman Z. Reducing immunization discomfort in 4- to 6-year-old children: A randomized clinical trial. Pediatrics 2009;124. https://doi.org/10.1542/peds.2007-3466.

[34] N. Y. Rika Sarfika and RW. Pengaruh Teknik Distraksi Kartun Animasi Terhadap Skala Nyeri Anak Usia Prasekolah Saat Pemasangan Infus di Instalasi Rawat Anak RSUP Dr. M. Djamil Padang. Ners J Keperawatan 2015;11:32-40.

[35] Vetri Buratti C, Angelino F, Sansoni J, Fabriani L, Mauro
L, Latina R. Distraction as a Technique to Control Pain in Pediatric Patients During Venipuncture. A narrative review of literature. Prof Inferm 2015;68:52-62. https://doi.org/10.7429/pi.2015.681052.

[36] Dengale RLCVRY. Assesment of Pain During Invasive Procedures Among Children (1 to 12 Years) admitted at Pravara Rural Hospital, Loni (bk). J Nurs Educ Res 2019;7:354-60.

[37] L. L. C. Ifigenia D. Mougianis and SWS. Parent-Child Behavioural Interactions During Pediatric Immunizations in Latino Sample. Clin Pr Pediatr Psychol 2017;5:209-20. 